\begin{tabular}{|c|c|c|}
\hline Chapter Title & \multicolumn{2}{|c|}{$\begin{array}{l}\text { Design and Cloning of Short HairpinRNAs (shRNAs) into a Lentiviral } \\
\text { Silencing Vector to Study the Function of Selected Proteins in } \\
\text { Neuronal Apoptosis }\end{array}$} \\
\hline Copyright Year & \multicolumn{2}{|l|}{2015} \\
\hline Copyright Holder & \multicolumn{2}{|c|}{ Springer Science+Business Media New York } \\
\hline \multirow[t]{8}{*}{ Corresp@ing Author } & Family Name & Canu \\
\hline & Particle & \\
\hline & Given Name & Nadia \\
\hline & \multicolumn{2}{|l|}{ Suffix } \\
\hline & Division & Department of System Medicine \\
\hline & Organization & University of "Tor Vergata" Rome \\
\hline & Address & $\begin{array}{l}\text { Via Montpellier 1, Rome, } 00137 \text {, } \\
\text { Italy }\end{array}$ \\
\hline & Email & cnanda00@uniroma2.it \\
\hline
\end{tabular}

Abstract

Double-stranded RNA-mediated interference (RNAi) is a new simple and fast research tool for shutting down genes and characterizes function of their respective proteins. Many strategies for design and delivery of siRNA to target cells are available. Here, we describe the use of lentiviral short hairpinRN $\bigcirc$ shRNA) RNA silencing to identify the involvement of D-serineracemase (SR)- an enzyme that syntheses D-serin $D$ modulate glutamate- $N$-methyl-D-aspartate receptor- in regulating ratcerebellar granule neurons (CGN) apoptosis. Apoptosis is induce serum and $\mathrm{KCl}$ withdrawal and is detected with fluorometric caspase 3assay.

Keywords

(separated by “-”)
siRNA - ShRNA - Lentivirus - Cerebellar granule cells - D-serine racemase 


\section{Design and Cloning of Short Hairpin RNAs (shRNAs) into a Lentiviral Silencing Vector to Study the Function of Selected Proteins in Neuronal Apoptosis}

\section{Abstract}

Double-stranded RNA-mediated interference (RNAi) is a new simple and fast research tool for shutting down genes and characterizes function of their respective proteins. Many strategies for design and delivery of siRNA to target cells are available. Here, we describe the use of lentiviral short hairpin RNA (shRNA) RNA silencing to identify the involvement of $\mathrm{D}$-serine racemase (SR)- an enzyme that syntheses $\mathrm{D}$-serine to modulate glutamate- $N$-methyl-D-aspartate receptor- in regulating rat cerebellar granule neurons (CGN) apoptosis. Apoptosis is induced by serum and $\mathrm{KCl}$ withdrawal and is detected with fluorometric caspase 3 assay.

Key words siRNA, ShRNA, Lentivirus, Cerebellar granule cells, D-serine racemase

.

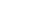

Gene knockout is used to study the function of specific gene, detect its protein product, and link it to physiological or pathological processes. Knockout can be deliberately made using different molecular techniques some of which, like homologous recombination, are lengthy and expensive. RNA interference (RNAi) has appeared as a novel pathway to knockdown specific mRNAs, thus preventing translation of the respective protein from occurring.

RNAi is a natural process - used in many different organisms to regulate endogenous gene expression-in which non-translated, long, double-stranded RNA (dsRNA) led to a strong, long lasting and specific silencing of selected genes [1]. Further studies revealed that small dsRNA of $21-25$ bp (small interfering $\mathrm{RNA}=$ siRNA) derived from endonuclease Dicer-mediated processing of long dsRNAs interact with a protein com ex to form the RNA-induced silencing complex (RISC) [2,3] is complex has nuclease activity and digests mRNA containing a base pair sequence identical to that in the siRNA. Thus, the siRNA serves 


\section{Author's Proof}

Nadia Canu

as a target sequence that allows RISC to recognize specific mRNAs and to prevent their translation by cleaving them [4]. Another method to produce siRNA is based on the use of short hairpin RNAs (ShRNAs) that trigger RNAi $[5,6]$. Short (6075 bp long) DNA oligodesoxynucleotides that form hairpins are cloned into a plasmid under the control of the $\mathrm{U} 6$ or $\mathrm{Hl}$ promoter for RNA polymerase III. Transfection of such a plasmid promotes the expression of ShRNAs that induce RNAi. Nonreplicating recombinant viral vectors (adeno, adeno-associated and lentiviruses) are commonly used for ShRNA expression in primary neuronal cells. Lentiviruses may be particularly suited for long-term ShRNA and expression and gene silencing in vivo since the viral DNA gets incorporated in the host genome.

Commonly used lentiviral vector systems belong to the second or third generation, ensuring safe application, as these viruses are unable to self-replicate, since the spontaneous selfassembly is prevented by distributing the least necessary number of virus elements on three and four plasmids, respectively. Here, we describe the methods used in our laboratory to silencing SR in rat CGNs as a tool for identifying the role of this enzyme during apoptosis.

\section{Materials}

\subsection{Design, Production, and Cloning of shRNAs and Preparation of Lentiviral Vectors}

1. Packaging cell line: HEK (human embryonic kidney)-293T (Invitrogen $^{\mathrm{TM}}$-Life Technologies ${ }^{\mathrm{TM}}$, Gaithersburg, MD). See Note 1.

2. $15 \mathrm{~cm}$ plates (Becton Dickinson Labware, Franklin Lakes, NJ).

3. Dulbecco's modified Eagle's medium (DMEM, Gibco ${ }^{\mathrm{TM}}$ Life Technologies ${ }^{\mathrm{TM}}$ ) with 2 and $10 \%$ fetal bovine serum (FBS). See Note 2.

4. Lipofectamine 2000 (Invitrogen $^{\mathrm{TM}}$-Life Technologies ${ }^{\mathrm{TM}}$ ).

5. Opti-MEM $1 \times\left(\right.$ Gibco $^{\mathrm{TM}}$ _Life Techonologies $\left.{ }^{\mathrm{TM}}\right)$.

6. Plasmids: pLVTHM; pCMVdR8.74; pMD2G (available from Addgene: http:/ /www.addgene.org/) for second lentivirus generation. For third lentivirus generation, refer to Dull et al. [7].

7. $10 \times$ Tris-buffered EDTA buffer (TBE buffer): 1 M Tris, $0.9 \mathrm{M}$ boric acid, 0.01 M EDTA.

8. Extraction Kit (DNA 70-10 kb): e.g., QIAquick Gel 8 (Quiagen GmbH, Hamburg, Germany).

9. Endotoxin-free plasmid maxipreps columns (Quiagen).

10. Tris-EDTA buffer (TE buffer $1 \times$ ): $10 \mathrm{mM}$ Tris, $1 \mathrm{mM}$ EDTA, pH 8.0 with $\mathrm{HCl}$.

11. Primer, $5^{\prime}$ forward must contain an MLu I site; Primer, $3^{\prime}$ reverse must contain a Cla I site. 


\section{Author's Proof}

12. Restriction endonucleases: MLu I, Cla I (New England 75 Biolabs, Ipswich, MA).

13. T4 DNA ligase $400,000 \mathrm{U} / \mathrm{mL}$ (New England Biolabs). $\quad 77$

14. $10 \times \mathrm{T} 4$ DNA ligase buffer: $50 \mathrm{mM}$ Tris- $\mathrm{HCl}, 10 \mathrm{mM} \mathrm{MgCl} 2, \quad 78$ $1 \mathrm{mM}$ ATP, $10 \mathrm{mM}$ DTT, pH 7.5.

15. Bacterial growth strain(s): DH5 $\alpha$ for $\mathrm{pMD} 2 \mathrm{G}$ and $\mathrm{pCMVdR} 8 ; 80$ HBI01 for pLVTHM lentiviral vector. See Note 3. 81

16. LB agar ampicillin plates: Use a $2 \mathrm{~L}$ flask to prepare $1 \mathrm{~L}$ of $\mathrm{LB} \quad 82$ broth with agar (Lennox) (Sigma Chemicals, St. Louis, MO). 83 To $1 \mathrm{~L}$ of distilled water add $35 \mathrm{~g}$ of LB agar. Swirl to dissolve 84 and autoclave for $15 \mathrm{~min}$ at $120^{\circ} \mathrm{C}$ to sterilize. Cool medium 85 to $50^{\circ} \mathrm{C}$, and add $50-100 \mu \mathrm{g} / \mathrm{mL}$ ampicillin. Pour into Petri 86 dishes and allow to solidify, store at $4{ }^{\circ} \mathrm{C}$. $\quad 87$

17. Hank's Buffered Salt Solution (HBSS): $0.137 \mathrm{M} \mathrm{NaCl}, 88$ $5.4 \mathrm{mM} \mathrm{KCl}, 0.25 \mathrm{mM} \mathrm{Na}_{2} \mathrm{HPO}_{4}, 0.1$ g glucose, $0.44 \mathrm{mM} \quad 89$

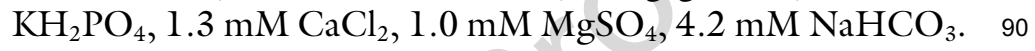

18. $20 \%[\mathrm{w} / \mathrm{v}]$ sucrose in HBSS. 91

2.2 Primary Cerebellar Granule Neuron Culture, Induction, and Detection of Apoptosis
1. Basal medium Eagle (BME; Life Technologies ${ }^{\mathrm{TM}}$ ). 92

2. Bovine serum albumin (BSA, Sigma Chemicals). 93

3. Krebs-Ringer bicarbonate medium (KRB): $120 \mathrm{mM} \mathrm{NaCl}, 94$ $5 \mathrm{mM} \mathrm{KCl}, 1.22 \mathrm{mM} \mathrm{KH}_{2} \mathrm{PO}_{4}, 25.5 \mathrm{mM}, 14 \mathrm{mM}$ glucose, 95 $4.2 \mathrm{mM}$ phenol red. $\quad 96$

4. Solution $\mathrm{A}$ : $\mathrm{KRB}$ supplemented with $1.2 \mathrm{mM} \mathrm{MgSO} 4,3 \mathrm{mg} / 97$ mL BSA. 98

5. DNAse I (Sigma Chemicals). 99

6. Soybean trypsin inhibitor (Sigma Chemicals). 100

7. Trypsin type III (Sigma Chemicals). 101

8. L-Glutamine. 102

9. Gentamicin sulfate. 103

10. Fetal bovine serum (FBS, Gibco ${ }^{\mathrm{TM}}$ ). 104

11. CGN culture medium: BME, 10 \% FBS, 25 mM KCl, 2 mM 105 glutamine, $100 \mathrm{mM}$ gentamicin sulfate. 106

12. 1 $\beta$-Arabinofuranosylcytosine (Sigma Chemicals). 107

13. Caspase 3 substrate: Ac-DEVD-AMC [N-Acetyl-Asp-Glu- 108 Val-Asp-AMC (7-amino-4-methyl coumarin)] (Biomol 109 International, Plymouth Meeting, PA). 110

14. Caspase 3 lysis buffer A: $10 \mathrm{mM}$ HEPES, $\mathrm{pH} 7.4,42 \mathrm{mM} 111$ $\mathrm{KCl}, 5 \mathrm{mMMgCl}_{2}, \quad \mathrm{mM}$, l $\mathrm{mM}$ PMSF, $0.5 \% 112$ 3 - [( 3 - cholamidopropyl)dime thyla m monio $]-1-113$ propanesulfonic acid (CHAPS), $1 \mu \mathrm{g} / \mathrm{mL}$ leupeptin. $\quad 114$

15. Caspase 3 assay buffer B: 25 mM HEPES, 1 mM EDTA, $0.1 \% 115$ CHAPS, $10 \%$ sucrose, 3 mM DTT, pH 7.5.

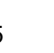

76

7

9

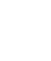

1




\section{Author's Proof}

Nadia Canu

\subsection{Western Blotting and Immuno- fluorescence for $D$-Serine Racemase}

1. Lysis buffer: $25 \mathrm{mM}$ Tris- $\mathrm{HCl}(\mathrm{pH} 7.6), 150 \mathrm{mM} \mathrm{NaCl}, 1 \%$ NP-40, 1 \% sodium deoxycholate, $0.1 \%$ SDS.

2. $10 \%$ SDS-PAGE (Sodium Dodecyl Sulfate-PolyAcrylamide Gel Electrophoresis)- Laemmli protocol:

(a) $10 \%$ lower gel (resolving gel): $4.9 \mathrm{~mL}$ distilled $\mathrm{H}_{2} \mathrm{O}$, $2.5 \mathrm{~mL} 40 \%$ acrylamide/Bis-acrylamide (29:1), $2.5 \mathrm{~mL}$ $1.5 \mathrm{M}$ Tris, $\mathrm{pH} 8.8,50 \mu \mathrm{L} 20 \%$ SDS, $50 \mu \mathrm{L} 10 \%$ ammonium persulfate, $10 \mu \mathrm{L}$ TEMED (total volume $=10 \mathrm{~mL}$ ). Mix well and quickly transfer the gel solution by using $1 \mathrm{~mL}$ pipette to the casting chamber between the glass plates. Once the gel has polymerized, prepare stacking gel.

(b) $3.75 \%$ stacking gel: $2.44 \mathrm{~mL}$ distilled $\mathrm{H}_{2} \mathrm{O}, 0.46 \mathrm{~mL} 40 \%$ acrylamide/Bis- acrylamide (29:1), $1 \mathrm{~mL} 0.5 \mathrm{M}$ Tris, $\mathrm{pH}$ 6.8, $40 \mu \mathrm{L} 10 \%$ SDS, $15 \mu \mathrm{L} 10 \%$ ammonium persulfate. Righ before pouring the gel add $1.5 \mu \mathrm{L}$ TEMED.

3. Agarose gel: agarose $1 \%$ in TBE buffer $0.5 \times$.

4. Phosphate-buffered saline $1 \times(\mathrm{PBS}): 137 \mathrm{mM} \mathrm{NaCl}, 2.7 \mathrm{mM}$ $\mathrm{KCl}, 10 \mathrm{mM} \mathrm{Na} \mathrm{HPO}_{4}, 1.8 \mathrm{mM} \mathrm{KH} \mathrm{PO}_{4}$.

5. Normal goat serum (NGS) (Jackson ImmunoResearch, Europe Ltd., Newmarket, UK).

6. $100 \%$ methanol.

7. Antifade mounting medium (ProLong ${ }^{\circledR}$ Gold Antifade-Life Technologies).

8. Mouse D-serine racemase antibody (BD Transduction laboratories $^{\mathrm{TM}}$, San Jose, CA).

9. Affinity purified-goat D-serine racemase antibody (Santa Cruz Biotechnology, Dallas, TX).

10. Secondary TRITC-conjugated donkey anti-goat antibody (Jackson ImmunoReseach Europe Ltd.).

\subsection{Equipment}

1. Centrifuge (e.g., Beckman Coulter Inc, Brea, CA).

2. Tissue culture $15 \mathrm{~cm}$ dishes.

3. Tissue culture 6-well dishes.

4. Tissue-culture 24-well dishes for CGNs (Nunc A/s, Roskilde, Denmark).

5. Filters $(0.22$ - or $0.45-\mu \mathrm{m})$.

6. Incubators preset to $37^{\circ} \mathrm{C}\left(5 \% \mathrm{CO}_{2}\right)$.

7. Microcentrifuge.

8. PCR thermocycler.

9. SW 28 and SW 55 rotors (Beckman Coulter).

10. Sterile round-bottom polypropylene tubes $5 \mathrm{~mL}$ (e.g., BD Falcon, BD Biosciences, San Jose, CA). 


\section{Author's Proof}

11. $50 \mathrm{~mL}$ tubes. 158

12. Centrifuge, polyallomer, $5 \mathrm{~mL}$ tubes (Beckman Coulter). 159

13. Centrifuge, polyallomer, $12 \mathrm{~mL}$ tubes (Beckman Coulter). 160

14. Microcentrifuge tubes. 161

15. Vortexer. 162

16. 96-Well plate fluorescence reader (EnVision, PerkinElmer, 163 Wellesley, MA). 164

17. Spectrofluorometer (e.g., Kontron AG, Zurich, Switzerland). 165

18. Protein electrophoresis/Western blotting apparatus. 166

19. Acrylamide gel electrophoresis apparatus. 167

20. Fluorescence microscope. 168

3 Methods

\subsection{Design, \\ Production, \\ and Cloning of shRNAs \\ and Preparation \\ of Lentiviral Vectors}

\subsubsection{Design of ShRNAs}

ShRNA oligonucleotide design describes the process of identifying target sequences within a gene of interest and designing the corresponding oligonucleotides to generate the ShRNA.

A number of algorithms may been utilized to predict effective siRNA sequences and design ShRNA (e.g., http://www.ambion. com/ or http://sfold.wadsworth.org/; http://eu.idtdna.com/ Scitools/Applications/shRNA etc). Here are general guidelines for ShRNA design based on the work of Tuschl et al. [8] and Elabishir et al. $[9,10]$ (see also: http://www.mpibpc.gwdg.de/ abteilungen/100/105/sirna.htmL).

1. Select a region of $19 \mathrm{nt}$ within the gene to be silenced [in our 180 case, rat D-serine racemase (NCBI accession number 181 NM_198757)] do not opt for region near the start codon (within 182 50-100 bases), nor untranslated regions [9, 10]. See Note 4.

2. Sequences that have at least $3 \mathrm{~A}$ or $\mathrm{T}$ residues in positions 15-19 of the sense sequence appear to have increased knockdown activity. See Note 5.

3. Ensure the content of GC of the 19 bases oligonucleotide between 40 and $60 \%$, and a GC content of approximately $45 \%$ is ideal.

4. Examine the 19 bases oligonucleotide for secondary structure and long base runs, both of which can interfere with the process of annealing.

5. Filter out, by appropriate database search, candidate targets that are present in other genes to avoid silencing of these loci. See Note 6.

6. Add the 7-9 nt hairpin loop sequence between sense and antisense strand [11-14]. One of the most effective loop sequences 197 for $\mathrm{Hl}$ promoter is TTCAAGAGA [15]. 


\section{Author's Proof}

Nadia Canu

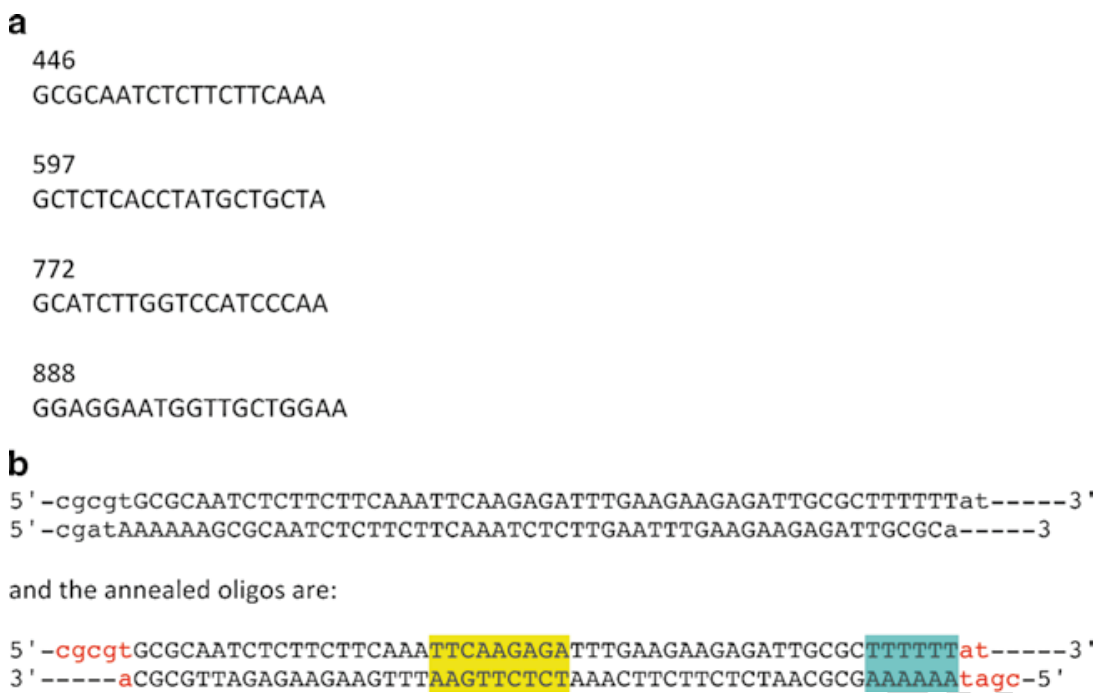

Fig. 1 (a) Potential RNAi target sequences identified in the rat SR-coding region. (b) For one of the chosen sequences (GCGCAATCTCTTCTTCAAA) the complementary oligonucleotide pair for the hairpin siRNA and the annealed oligonucleotides are reported. The TTCAAGAGA loop sequence is highlighted in yellow, the stretch T is highlighted in light blue and the restriction sites (MLu I and Cla I) in red lowercase

7. Place a stretch of $5-6 \mathrm{~T}$ at the end of ShRNA to guarantee the termination of RNA polymerase III transcription.

8. Add to the end of two complementary oligonucleotides restriction sites (in our case MLu I at $5^{\prime}$ and Cla I at $3^{\prime}$ ) (see Fig. 1).

9. Include a negative control ShRNA. Usually ShRNA design online tools returns a scrambled sequence with the same nucleotide composition as your siRNA/shRNA input sequence.

10. Sense and antisense oligos must be phosphorylated and PAGE purified in order to increase cloning efficiency. When ordering, be sure to require that oligonucleotides are supplied after PAGE purification.

3.1.2 Annealing of shRNA Oligonucleotides
For expedience, annealing can be done in a thermal cycler.

1. Resuspend each PAGE-purified oligonucleotide in TE buffer to a concentration of $100 \mu \mathrm{M}$.

2. Mix the oligos for the sense strand and the anti strand at a $1: 1$ ratio. This will ultimately give $50 \mu \mathrm{M}$ of ds oligonucleotide (assuming $100 \%$ theoretical annealing).

3. Heat the mixture to $95{ }^{\circ} \mathrm{C}$ for 30 s. See Note 7.

4. Heat at $72^{\circ} \mathrm{C}$ for $2 \mathrm{~min}$.

5. Heat at $37^{\circ} \mathrm{C}$ for $2 \mathrm{~min}$.

6. Heat at $25^{\circ} \mathrm{C}$ for $2 \mathrm{~min}$.

7. Store on ice or at $-20^{\circ} \mathrm{C}$ until use. 


\section{Author's Proof}

3.1.3 Cloning ShRNA Oligonucleotides into pLVTHM
3.1.4 Preparation of Lentiviral Vectors
1. Dilute the annealed oligonucleotides with TE buffer to obtain 221 a concentration of $0.5 \mu \mathrm{M}$.

2. For each ligation, add the following reagents in a microfuge tube:

- $2 \mu \mathrm{L}$ digested (MLu I/Cla I) and dephosphorylated 224 pLVTHM vector $(100 \mathrm{ng} / \mu \mathrm{L})$. 225

- $\quad 4 \mu \mathrm{L}$ diluted, annealed oligonucleotide $(0.5 \mu \mathrm{M})$. 226

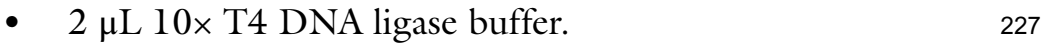

- $0.5 \mu \mathrm{L}$ BSA $(10 \mathrm{mg} / \mathrm{mL})$. 228

- $\quad 11 \mu \mathrm{L}$ Nuclease-free $\mathrm{H}_{2} \mathrm{O}$. 229

- $\quad 0.5 \mu \mathrm{L}$ T4 DNA ligase $(400 \mathrm{U} / \mu \mathrm{L})$.

- For a $20 \mu \mathrm{L}$ total volume. 231

3. Set up separate ligation using $2 \mu \mathrm{L}$ of the negative scramble 232 control ShRNA annealed oligonucleotide. 233

4. Set up separate ligation using $2 \mu \mathrm{L}$ of digested (MLu I/Cla I) 234 pLVTHM vector $(50 \mathrm{ng} / \mu \mathrm{L})$ without annealed oligonucleotide. 235

5. Incubate ligation mixture at room temperature for $3 \mathrm{~h}$. See 236 Note 8.

6. Transform immediately competent bacteria (with high trans- 238 formation efficiency) and select on ampicillin plates. 239

7. Digest plasmid DNA from colonies with MLu I/Cla I and run 240 on a $12 \%$ DNA polyacrylamide gel in TBE $1 \times$ buffer gel $($ See 241 Note 9). Positive clones will contain an approximately 60-bp 242 insert compared to $17 \mathrm{bp}$ for colonies without an insert. 243

8. Sequence the insert with human $\mathrm{Hl}$ primer (TCGNTATGTG 244 TTCTGGGAAA) to check hairpin integrity. 245

9. Validate, by Western blot analysis or indirect immunofluores- 246 cence, the cloned ShRNA cassettes by transfecting pLVHTM- 247 ShRNA as well as scramble vector in cell line that coexpresses 248 the target gene. In our case, the cDNA for D-serine racemase 249 together with ShRNA silencing cassette were transfected in an 250 highly transfectable cell line (e.tHEK-293). See Note 10. 251

You need to observe Biosafety-level-2since application of this pro- 252 tocol leads to the production of pseudoviral particles capable of 253 infecting mammalian cells. 254

1. For a $10 \mathrm{~cm}$ dish lentiviral preparation: plate lentivirus HEK- 255 293-T cells at a density of approximately 100 cells $/ \mathrm{mm}^{2}$ in 256 $10 \mathrm{~mL}$ of DMEM, supplemented with $10 \%$ FBS, 12-24 h 257 before transfection. Addition of antibiotic solution does not 258 interfere with transfection. 259

2. To increase cell adherence, precoat twelve $15 \mathrm{~cm}$ dishes with 260 $10 \mathrm{~mL}$ of poly-L-lysine, incubate for $30 \mathrm{~min}$ at room temperature 261 


\section{Author's Proof}

Nadia Canu

under UV, and aspirate off the liquid. Grow the cells overnight at $37^{\circ} \mathrm{C}$ in $5 \% \mathrm{CO}_{2}$. See Note 11.

3. Aliquot in $200 \mu \mathrm{L}$ of Opti-MEM the three plasmids into a sterile polypropylene tube. For a $10 \mathrm{~cm}$ dish, use:

- $-10 \mu \mathrm{g}$ of lentivector pLVTHM.

- $\quad-3.5 \mu \mathrm{g}$ of pMD2G (Gag-Pol).

- $\quad-6.5 \mu \mathrm{g}$ of pCMVdR8.74.

4. In a separate tube, dilute $20 \mu \mathrm{L}$ lipofectamine 2000 in $200 \mu \mathrm{L}$ of Opti-MEM $1 \times$.

5. Add diluted lipofectamine reagent drop-wise to the DNA solution while gently vortexing the DNA-containing tube and incubate for $30 \mathrm{~min}$ at room temperature. See Note 12.

6. Remove medium from cell plate, wash cells twice with Opti-MEM and add $5 \mathrm{~mL}$ of Opti-MEM without antibiotics. See Note 13.

7. Add the transfection mixture to each plate. Swirl the plates gently to distribute the complex and incubate overnight at $37^{\circ} \mathrm{C}$ in a $5 \% \mathrm{CO}_{2}$ atmosphere.

8. Approximately 6-8 h after transfection, remove media. Add $15 \mathrm{~mL}$ of fresh DMEM plus $2 \%$ heat-inactivated FBS and penicillin-streptomycin to each plate and incubate overnight at $37^{\circ} \mathrm{C}$ in a $5 \% \mathrm{CO}_{2}$ atmosphere. See Note 14.

9. Collect the supernatant from the plates and centrifuge at $500 \times g$ for $10 \mathrm{~min}$ to remove cell debris and filter through $0.45 \mu \mathrm{m}$ filters. See Note 15 .

10. Add $15 \mathrm{~mL}$ of fresh medium to each plate and incubate overnight. Filtered supernatants can be stored for several days at $4{ }^{\circ} \mathrm{C}$.

11. Collect media and filter as in step 9. See Note 16.

12. Pool collected supernatants from steps 9 and 11. Transfer to Beckman tubes using 25-29 mL per tube.

13. Concentrate viral particles by centrifuging in a Beckman SW 28 rotor at $65,000 \times g$ or $2 \mathrm{~h}$ at $20^{\circ} \mathrm{C}$.

14. Resuspend all pellets in a total of $1 \mathrm{~mL}$ of HBSS and wash tubes a second time with $1 \mathrm{~mL}$ of HBSS.

15. Increase the combined volume from 2 to $3 \mathrm{~mL}$ with HBSS and layer the resuspended pellets on $1.5 \mathrm{~mL}$ of a $20 \%$ sucrose (in HBSS) cushion in Beckman tubes.

16. Centrifuge using a Beckman SW 55 rotor at $53,500 \times g$ for $1.5 \mathrm{~h}$ at $20^{\circ} \mathrm{C}$.

17. Resuspend the pellet in $100 \mu \mathrm{L}$ of HBSS containing $1 \% \mathrm{BSA}$ and wash the tube with an additional $100 \mu \mathrm{L}$ of HBSS containing $1 \%$ BSA. Shake the resuspended viral preparation on a low-speed vortexer for 15-30 min. Centrifuge for $10 \mathrm{~s}$ to remove debris. 


\section{Author's Proof}

18. Aliquot the cleared viral solution and store at $-80^{\circ} \mathrm{C}$. It can be 304 stored for many months. Avoid repeated freeze-thaw cycles. 305

19. Titrate the viral preparations by biological titration using GFP, 306 which is the marker contained in the lentivector. The fraction 307 of GFP fluorescent cells can be counted by FACS (fluores- 308 cence activated cell sorting). GFP fluorescence may be also 309 visualized under a fluorescence microscope. Usually 10-15 310 random fields of view are used to estimate the overall fraction 311 of fluorescing cells in each well.

\subsection{Primary Cerebellar Granule Neuron Cultures and Lentivirus Transduction}

3.2.1 Primary Cerebellar Granule Neuron Cultures

3.2.2 Transduction of Primary Cerebellar Granule Neuron Cultures
Cultures enriched in CGNs are obtained from dissociated cerebella of 8-day-old Wistar rats according to Levi et al. [16]. The preparation of CGN cultures is carried out at Day 1, transduction at Day 2, induction and detection of apoptosis at Days 6-7.

1. Remove 4-5 cerebella from 8-day-old rats and slice them (0.4 mm thickness) with a mechanical tissue chopper.

2. Suspend in $10 \mathrm{~mL}$ solution $\mathrm{A}$, centrifuge for $15 \mathrm{~s}$ at $150 \times \mathfrak{g}$. $\quad 319$

3. Resuspend the tissue in $10 \mathrm{~mL}$ solution A containing $0.25 \mu \mathrm{g} / 320$ $\mathrm{mL}$ trypsin III and incubate at $37^{\circ} \mathrm{C}$ for $15 \mathrm{~min}$ in a shaking 321 water bath at rate of $125 \mathrm{rpm}$.

4. Add to the suspension $10 \mathrm{~mL}$ solution A containing $12.8 \mu \mathrm{g} \quad 323$ DNAase I and $83 \mu \mathrm{g}$ soybean trypsin inhibitor. 324

5. Centrifuge immediately for $15 \mathrm{~s}$ at $150 \times g$. 325

6. Resuspend the pellet in $2 \mathrm{~mL}$ of solution A containing $80 \mu \mathrm{g} \quad 326$ DNAase I, $0.52 \mathrm{mg}$ soybean trypsin inhibitor and $2.7 \mathrm{mM} 327$ $\mathrm{MgSO}_{4}$. Triturate the tissue with a Pasteur pipette (25 strokes). 328

7. Allow the suspension to stand for $15 \mathrm{~min}$, aspirate carefully 329 the upper $1.5 \mathrm{~mL}$, readjust the volume to about $2 \mathrm{~mL}$ ad dis- 330 sociate as above. After allowing the suspension to stand for 331 $15 \mathrm{~min}$, take off the supernatant, leaving only $0.2 \mathrm{~mL}$ contain- 332 ing clumps and debris.

8. Transfer the supernatant into $3 \mathrm{~mL}$ Solution A containing 334 $0.1 \mathrm{mM} \mathrm{CaCl}_{2}$. After about $10 \mathrm{~min}$ decant the supernatant, 335 allow to stand for another $10 \mathrm{~min}$ and resuspend the pellet in 336 CGN cultur Dindium. 337

9. Count the cell in $\rightarrow 338$

10. Plate $4 \times 10^{5}$ CGN per well in a NUNC 24-well plate in $800 \mu \mathrm{L} \quad 339$ CGN culture medium. Incubate the cells at $37{ }^{\circ} \mathrm{C}$ with $5 \% \mathrm{CO}_{2} . \quad 340$

11. After $24 \mathrm{~h}$ add $10 \mu \mathrm{M} 1 \beta$-Arabinofuranosylcytosine to CGN 341 culture medium to prevent proliferation of non-neuronal cells. 342

1. Transduce CGN cells with lentivirus. For each well, prepare 343 $50 \mu \mathrm{L}$ of virus suspension diluted in CGN culture medium (See 344 Note 17). To transduce CGN reduce the volume of the 345 


\section{Author's Proof}

Nadia Canu

\subsection{Induction} and Detection of Apoptosis

\subsubsection{Induction} of Apoptosis

3.3.2 Detection of Apoptosis medium to one-third; add the recombinant lentivirus at different dilutions. Allow the virus to adsorb for $1-2 \mathrm{~h}$, thus render back the medium to its original volume. Then cultivate neurons up to 6-7 days in vitro (DIV) when apoptosis will be induced (Fig. 1).

Induction of apoptosis is carried out in serum-free medium at low (5 $\mathrm{mM}) \mathrm{KCl}$ [17].

1. Wash cultures twice and maintain in serum-free low ( $5 \mathrm{mM})$ $\mathrm{KCl}$ CGN culture medium for $8 \mathrm{~h}$.

2. Wash and maintain control cultures in serum-free CGN culture medium for $8 \mathrm{~h}$.

Measure caspase 3 activity as follows:

1. Wash 500,000 CGNs with PBS once.

2. Add $100 \mu \mathrm{L}$ of caspase 3 lysis buffer A to lyse cells.

3. Combine $25 \mathrm{~L}$ of lysate with $75 \mu \mathrm{L}$ of caspase 3 assay buffer $\mathrm{B}$ containing $30 \mu \mathrm{M}$ Ac-DEVD-AMC.

4. Incubate for $20 \mathrm{~min}$ at room temperature.

5. Measure fluorescence at an excitation of $380 \mathrm{~nm}$ and an emission of $460 \mathrm{~nm}$ using a spectrofluorometer (Fig. 2).

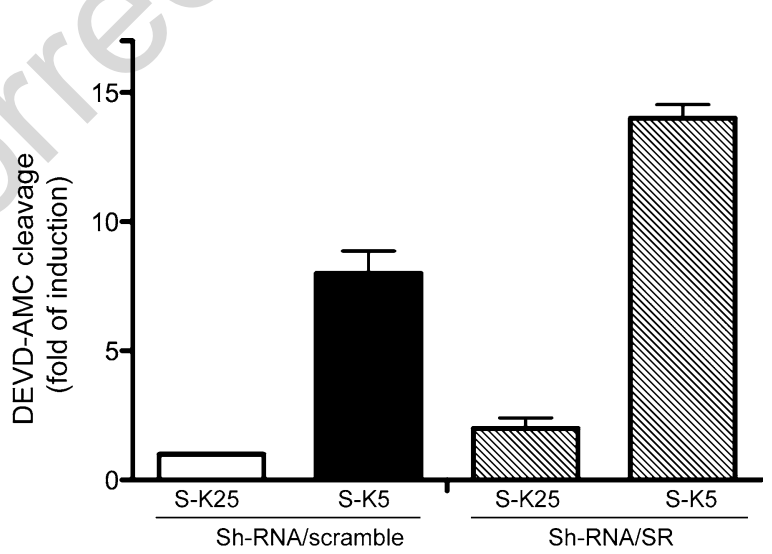

Fig. 2 In vitro CGNs (2 DIV) were ducted either with Sh-RNA/scramble and Sh-RNA/SR lentivirus at MOI 40. At 6DIV they were induced to undergo apoptosis by serum and $\mathrm{KCl}$ deprivation (S-K5); control cells were maintained in serumfree medium supplemented with $25 \mathrm{mM} \mathrm{KCl}$ (S-K25). Eight hours after apoptosis induction neurons were lysed and assayed for DEVD-MCA cleavage. Foldinduction of caspase- 3 activity is the mean $( \pm S E M)$ of triplicate determinations from three independent experiments. Note that silencing of SR increases caspase-3 activity in CGNs undergoir (1) poptosis, suggesting that this enzyme has a protective role in survival of CGlv(see ref. 17) 


\section{Author's Proof}

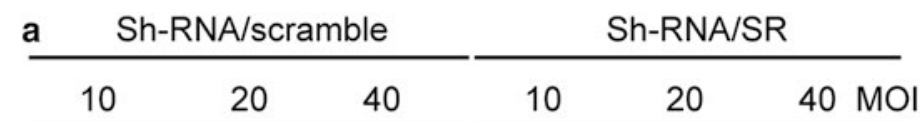

\begin{tabular}{|c|c|c|c|c|c|}
\hline$-10=0$ & $20=0$ & 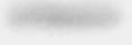 & reneses & tiseses & $x_{2}=2$ \\
\hline
\end{tabular}
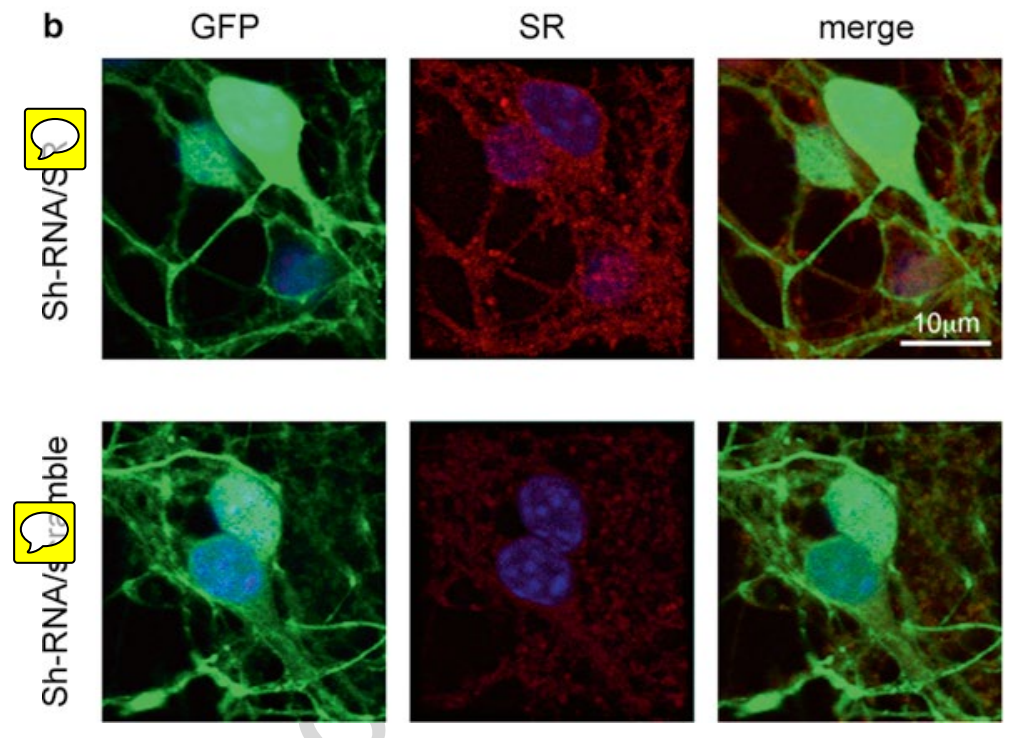

Fig. 3 (a) In vitro CGNs (2 DIV = day in vitro) were trans (UC) ed either with Sh-RNA/ scramble and Sh-RNA/SR lentivirus at MOI indicated. AT bDIV lysates were processed for SDS-PAGE and Western blot for immunodetection of SR and $\beta$-actin as control of silencing efficiency and specificity. (b) Confocal microscope analysis of SR expression at 6 DIV (red) in Sh-RNA/scramble and Sh- SR transducted CGNs at 2DIV at MOI 40. Fransdu/recommended guidelines

3.4 Western Blotting and Immunofluorescence for $D$-Serine Racemase

\subsubsection{Western Blotting}

\subsubsection{Immuno-}

fluorescence
1. Extract total proteins by scraping cells in SDS-reducing sample 365 buffer.

2. Boil for $5 \mathrm{~min}$.

3. Perform western blot analysis with mouse anti-D-serine racemase antibody (see Fig. 3a).

1. Fix and permeabilize CGN cultured in the chamber slide with 370 methanol $100 \%$ for $20 \mathrm{~min}$ at $-20{ }^{\circ} \mathrm{C}$. 371

2. Block with $4 \%$ NGS in PBS for $1 \mathrm{~h}$ at room temperature. 372

3 . Incubate slides with affinity purified-goat anti-D-serine race- 373 mase antibody diluted 1:50 in PBS overnight at $4{ }^{\circ} \mathrm{C}$. 374

4. Wash three times with PBS. 


\section{Author's Proof}

Nadia Canu

5. Add secondary TRITC-conjugated donkey anti-goat antibody diluted 1:200 in PBS and incubate at room temperature for $30 \mathrm{~min}$ in a humid chamber.

6. Wash three times with PBS.

7. Remove excess moisture from the slide before adding anti-fade mounting medium.

8. Examine slide under fluorescence/confocal microscope (see Fig. 3b).

\section{Notes}

1. Cells should be of low-passage number and should not be used after passage 20 or if growth is slow.

2. Certain brands of FBS do not support efficient transfection and can result in low viral titers. We routinely use FBS, Qualified, Australia Origin from Gibco ${ }^{\mathrm{TM}}$.

3. There is an additional Cla I site in PLVTHM vector that is blocked by Dam methylation. The plasmid needs to be grown in a $\mathrm{Dam}^{+}$ bacterial strain such $\mathrm{HBl} 01$ in order to use Cla I for cloning.

4. Although it is recommended to avoid to select target sequence in the untranslated regions, since regulatory protein binding to regions in and near the untranslated region might interfere with the RNAi process, in some case targets within the untranslated regions (UTR) have been also reported [18].

5. Avoid selecting target sense or antisense sequences that contain a consecutive run of three or more thymidine residues; a poly $(\mathrm{T})$ tract within the sequence can potentially cause premature termination of the shRNA transcript.

6. Many online tools to design shRNA gives a link to the NCBI BLAST server to search for similarity of the suggested target against the mRNA database of the organism of interest.

7. Heating to $95{ }^{\circ} \mathrm{C}$ is essential to remove all secondary structure, disrupt the internal hairpin of each oligonucleotide and promote intermolecular annealing.

8. If you are unable to perform immediately transformation, store ligation at $-20^{\circ} \mathrm{C}$.

9. See Tables 5 and 6 in Sambrook and Russell, Molecular Cloning 3rd Ed VIII, p5.42 for different acrylamide concentrations and the effective range of DNA fragment sizes separated.

10. We have transfected $200 \mathrm{ng}$ of target cDNA plasmid (HA-Dserine racemase) plus 500-1,000 ng of the plasmid containing the silencing cassette per 6-well plate and harvest the cells for immunoblot analysis $48-72 \mathrm{~h}$ after transfection. 


\section{Author's Proof}

11. For best result and to optimize viral titer cells must be at 417 70-80 \% confluence, equably distributed and with flat mor- 418 phology before transfection. $\quad 419$

12. The DNA-lipofectamine complex must be formed in the 420 absence of proteins even though the complex is able to transfect 421 cells in the presence of proteins such as $10 \%$ FBS. Opti-MEM I 422 is recommended for diluting both DNA and lipofectamine 423 reagent. The ratio of $2.0 \mu \mathrm{L}$ of lipofectamine 2000 per $1 \mu \mathrm{g}$ of 424 plasmid has been found to be optimal. Increasing the ratio does 425 not further improve transfection efficiency. 426

13. Though the complex is able to transfect cells in the presence 427 of proteins such as $10 \%$ FBS, we found an improved transfec- 428 $\begin{array}{ll}\text { tion efficiency in the absence of serum. } & 429\end{array}$

14. To increase the lentivirus titer we have added, caffeine to a final 430 concentration of 2-4 mM for 17-40 h post-transfection [19]. 431

15. Do not use nitrocellulose filters, as nitrocellulose is known to 432 bind lentivirus and reduce titers. Use $0.45 \mu \mathrm{m}$ polyethersul- 433 fone (PES) low protein-binding filters. 434

16. Peak of virus production is normally achieved $24-48$ h post- 435 transfection; however collecting medium at multiple times at 436 36,48 , and $60 \mathrm{~h}$ post-transfection increases the viral yield. $\quad 437$

17. Use several multiplicity of infection (MOI) virus stock to find 438 the more suitable MOI to obtain silencing of you gene of 439 interest. In addition, include a transduction with the scramble 440 control and other appropriate positive and negative controls. 441 Mix the virus with the medium gently by inverting the tubes 442 several times. Do not vortex.

\section{Acknowledgments}

This work was supported by grants from Italian Ministry of Education, University and Research (PRIN 2009, 2009KP83CR-02 to NC).

\section{References}

1. Fire A, Xu S, Montgomery MK, Kostas SA, Driver SE et al (1998) Potent and specific genetic interference by double-stranded RNA in Caenorhabditis elegans. Nature 391:806-811

2. Hannon GJ (2002) RNA interference. Nature 418:244-251

3. Dykxhoorn DM, Novina CD, Sharp PA (2003) Killing the messenger: short RNAS that silence gene expression. Nature 4:457-467

4. Hammond SM (2005) Dicing and slicing the core machinery of the RNA interference pathway. FEBS Lett 579:5822-5829
5. Yu JY, DeRuiter SL, Turner DL (2002) RNA interference by expression of short-interfering RNAs and hairpin RNAs in mammalian cells. Proc Natl Acad Sci U S A 99:6047-6052

6. Paddison PJ, Caudy AA, Bernstein E, Hannon GJ, Conklin DS (2002) Short hairpin RNAs (shRNAs) induce sequence-specific silencing in mammalian cells. Genes Devel 16:948-958

7. Dull T, Zufferey R, Kelly M, Mandel RJ, Nguyen M et al (1998) J Virol 72:8463-8471

8. Tuschl T (2006) Selection of siRN sepuences for Mammalian RNAi. CSH Proto
460 


\section{Author's Proof}

Nadia Canu

9. Elbashir SM, Martinez J, Patkaniowska A, Lendeckel W, Tuschl T (2001) Functional anatomy of siRNAs for mediating efficient RNAi in Drosophila melanogaster embryo lysate. EMBO J 20:6877-6888

10. Elbashir SM, Harborth J, Lendeckel W, Yalcin A, Weber K et al (2001) Duplexes of 21-nucleotide RNAs mediate RNA interference in cultured mammalian cells. Nature 41 1:494-498

11. Vermeulen A, Behlen L, Reynolds A, Wolfson A, Marshall W et al (2005) The contributions of dsRNA structure to Dicer specificity and efficiency. RNA 11:674-682

12. Hannon GJ, Rossi JJ (2004) Unlocking the potential of the human genome with RNA interference. Nature 431:371-378

13. Gönczy P, Schnabel H, Kaletta T, Amores AD, Hyman T et al (1999) Dissection of cell division processes in the one cell stage Caenorhabditis elegans embryo by mutational analysis. J Cell Biol 144:927-946

14. Jantsch-Plunger V, Glotzer M (1999) Depletion of syntaxins in the early
Caenorhabditis elegans embryo reveals a role for membrane fusion events in cytokinesis. Curr Biol 9:738-745

15. Brummelkamp TR, Bernards R, Agami R 498 (2002) A system for stable expression of short 499 interfering RNAs in mammalian cells. Science 500 296:550-553

16. Levi G, Aloisi F, Ciotti MT, Gallo V (1984) Autoradiografic localization and depolarizationinduced release of acidic aminoacids in differentiating cerebellar granule cultures. Brain Res 290:77-86

17. Esposito $S$, Pristerà A, Maresca G, Cavallaro $S$, Felsani A et al (2012) Contribution of serine racemase/d-serine pathway to neuronal apoptosis. Aging Cell 11:588-598

18. Anthony KG, Bai F, Krishnan MN, Fikrig E, 511 Koski RA (2009) Effective siRNA targeting of 512 the 3 ' untranslated region of the West Nile 513 virus genome. Antiviral Res 82:166-168 514

19. Ellis BL, Potts PR, Porteus MH (2011) 515 Creating higher titer lentivirus with caffeine. 516 Hum Gene Ther 22:93-100 
